\title{
Sistem Pengendalian Internal Pemerintah, Sistem Informasi Manajemen Keuangan Daerah, Good Governance dan Kualitas Laporan Keuangan di Kabupaten Jembrana
}

\author{
Ida Bagus Putu Julio Swastika ${ }^{1}$ \\ Fakultas Ekonomi dan Bisnis \\ Universitas Udayana, Indonesia
}

\author{
Ni Luh Sari Widhiyani² \\ Fakultas Ekonomi dan Bisnis \\ Universitas Udayana, Indonesia
}

Surel : julioswastika69@gmail.com

\section{ABSTRAK}

Tujuan penelitian ini adalah untuk mengetahui pengaruh sistem pengendalian intern pemerintah, sistem informasi manajemen keuangan daerah dan good governance pada kualitas laporan keuangan daerah. Penelitian ini dilakukan di Pemerintahan Kabupaten Jembrana. Jumlah sampel yang diambil sebanyak 50 orang pegawai dengan menggunakan purposive sampling method. Pengumpulan data dilakukan melalui kuesioner dan dokumentasi. Teknik analisis yang digunakan adalah regresi linier berganda. Berdasarkan hasil analisis menunjukkan bahwa sistem pengendalian intern pemerintah, sistem informasi manajemen keuangan daerah dan good governance berpengaruh positif pada kualitas laporan keuangan daerah Kabupaten Jembrana. Hal ini berarti bahwa semakin baik sistem pengendalian intern pemerintah, sistem informasi manajemen keuangan daerah dan good governance yang diterapkan dalam pemerintahan daerah maka semakin tinggi kualitas laporan keuangan daerah yang dihasilkan.

Kata Kunci: SPIP; SIMDA; Good Governance; Kualitas Laporan Keuangan Daerah.

\section{Government Internal Control System, Regional Financial Management Information System, Good Governance and Quality of Financial Statements in Jembrana Regency}

\begin{abstract}
The purpose of this study was to determine the effect of government internal control systems, regional financial management information systems and good governance on the quality of regional financial reports. This research was conducted in Jembrana Regency Government. The number of samples taken was 50 employees using a purposive sampling method. Data collection is done through questionnaires and documentation. The analysis technique used is multiple linear regression. Based on the results of the analysis shows that the government's internal control system, regional financial management information systems and good governance have a positive effect on the quality of regional financial reports in Jembrana Regency. This means that the better the government's internal control system, the regional financial management information system and good governance implemented in regional government, the higher the quality of the regional financial reports produced.
\end{abstract}

Keywords: SPIP; SIMDA; Good governance; Quality of Regional Financial Statements.

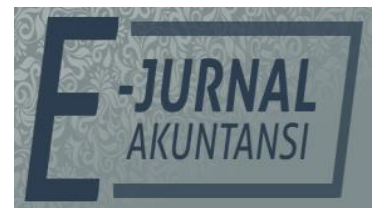

e-ISSN 2302-8556

Vol. 30 No. 11

Denpasar, Nopember 2020

Hal. 2724-2736

DOI:

10.24843/EJA.2020.v30.i11.p02

PENGUTIPAN:

Swastika, I.B.P.J. \&

Widhiyani, N.L.S. (2020).

Sistem Pengendalian Internal

Pemerintah, Sistem

Informasi Manajemen

Keuangan Daerah, Good

Governance Dan Kualitas

Laporan Keuangan di

Kabupaten Jembrana. E-

Jurnal Akuntansi, 30(11),

2724-2736

RIWAYAT ARTIKEL:

Artikel Masuk: 10 Mei 2020

Artikel Diterima: 7 Juli 2020

Artikel dapat diakses : https://ojs.unud.ac.id/index.php/Akuntansi/index 


\section{PENDAHULUAN}

Laporan keuangan yang bekualitas memiliki akuntabilitas yang baik serta memenuhi standar-standar akuntansi yang berlaku dan memenuhi karakteristik laporan keuangan yang ada maka laporan keuangan dapat dikatakan berkualitas. Laporan keuangan yang berkualitas dihasilkan oleh Sumber Daya Manusia (SDM) yang berkompeten dibidang pengelola keuangan. SDM harus memiliki kompetensi di bidang akuntansi dalam pembuatan laporan keuangan yang sesuai dengan standar akuntansi pemerintahan agar laporan keuangan tersebut memiliki kualitas yang baik. Kualitas laporan keuangan pemerintah merupakan cerminan kinerja pemerintah daerah, maka dari itu pemerintah perlu meningkatkan kualitas laporan keuangannya, namun sudah merupakan permasalahan umum yang terjadi di pemerintahan khususnya pemerintah daerah bahwa untuk menerapkan manajemen sumber daya manusia seringkali yang dilakukan tidak sesuai dengan kebutuhan baik secara kuantitas maupun kualitas. Peneliti terdahulu yang sudah meneliti tentang kualitas laporan keuangan daerah menghasilkan banyak faktor yang mempengaruhi kualitas laporan keuangan daerah di antaranya adalah sistem pengendalian intern pemerintah, sistem informasi manajemen keuangan daerah dan good governance.

Sistem Pengendalian Intern Pemerintah (SPIP) terdiri dari beberapa unsur, yaitu lingkungan pengendalian, penilaian risiko, kegiatan pengendalian, informasi dan komunikasi, pemantauan pengendalian intern. Berdasarkan PP 60 Tahun 2008, bahwa seluruh proses kegiatan audit, review, evaluasi, pemantauan dan kegiatan pengawasan lain terhadap penyelenggaraan tugas dan fungsi organisasi dalam rangka memberikan keyakinan yang memadai bahwa kegiatan telah dilaksanakan sesuai dengan tolak ukur yang telah dilakukan secara efektif dan efisien dalam mewujudkan tata kepemerintahan yang baik disebut dengan Pengawasan Intern. Namun, yang terjadi di masyarakat yang menggambarkan pengelolaan keuangan belum berjalan sepenuhnya antara lain, tingkat korupsi yang masih tinggi, adanya kebocoran anggaran yang timbul akibat praktek pencairan anggaran yang tidak sesuai dengan anggaran belanja yang tersedia, sementara penerima anggaran harus mempertanggungjawabkan sesuai dengan anggaran yang ditetapkan. Akibatnya penerima anggaran berusaha untuk memperoleh bukti transaksi guna mendukung pertanggungjawaban realisasi anggaran sebagai wujud akuntabilitas keuangan instansi pemerintah daerah yang diragukan kebenarannya, sehingga diperlukannya alat pengendali yang disebut dengan Sistem Pengendalian Intern Pemerintah Widyaningsih (2009). Anggota Badan Akuntabilitas Keuangan Negara (BAKN) Nur Yasin menjelaskan bahwa akar permasalahan rendahnya kualitas dalam pengelolaan keuangan negara di Indonesia adalah kegagalan Kementerian, Lembaga Negara, BUMN/BUMD, Pemerintah Daerah dan lembaga negara lainnya dalam mengimplementasikan SPIP Insani (2010). Penelitian terdahulu mengenai kualitas laporan keuangan daerah dilakukan oleh Susilawati \& Dwi Seftihani Riana (2014) yang menyimpulkan bahwa penerapan Standar Akuntansi Pemerintahan, Sistem Pengendalian Intern berpengaruh terhadap kualitas laporan keuangan daerah. SPIP berpengaruh positif pada kualitas laporan keuangan daerah disimpulkan juga oleh Sudiarianti (2015). Penelitian Desianawati (2014) juga menyatakan SPIP yang diterapkan pada sistem di 
pemerintah daerah mempunyai dampak yang signifikan pada kualitas laporan keuangan daerah. Sedangkan penelitian yang dilakukan Indriya (2013) menyatakan sebaliknya bahwa SPIP berpengaruh negatif pada kualitas laporan keuangan daerah.

Sistem Informasi Manajemen Keuangan Daerah (SIMDA) merupakan sistem pengelolaan data keuangan yang di gunakan pada seluruh pemerintahan daerah yang ada Indonesia. Perkembangan teknologi yang begitu pesat merupakan salah satu faktor yang melatar belakangi dikembangkannya suatu sistem informasi yang bersifat komputer untuk memudahkan pengelolaan keuangan pada organisasi pemerintah daerah maka dikembangkan Aplikasi Sistem Informasi Manajemen Keuangan Daerah atau SIMDA. SIMDA telah diterapkan oleh pemerintah Kabupaten Jembrana sebagai sistem informasi pengelolaan dan pelaporan keuangan dan barang milik daerah. Sejak diterapkannya SIMDA dapat dilihat adanya kemajuan dalam sistem keuangan yang mempermudah pembuatan Laporan Keuangan dimana hasil pemerikasaan BPK menyatakan laporan keuangan Pemerintah Kabupaten Jembrana adalah WTP, namun demikian masih terdapat masalah perangkapan tugas dan ketidaksesuaian pelaksanaan prosedur dalam proses pengelolaan keuangan daerah melalui SIMDA tersebut.

SIMDA mulai diperkenalkan pada tanggal 29 Agustus 2006. Program aplikasi ini dikembangkan oleh BPKP guna membantu pengelolaan keuangan daerah ditingkat Satuan Kerja Perangkat Daerah (SKPD). Adanya program aplikasi ini diharapkan dapat memberikan manfaat lebih kepada pemerintah daerah dalam melaksanakan pengelolaan keuangan daerah. Aplikasi SIMDA dapat diimplementasikan untuk pengelolaan keuangan daerah secara terintegrasi, menggunakan teknologi client server, dari penyusunan anggaran, pelaksanaan anggaran dan pertanggungjawaban keuangan. Namun menurut Devi (2013) berdasarkan hasil penelitiannya menyatakan bahwa SIMDA belum sepenuhnya digunakan secara optimal, yang menyebabkan penerapan SIMDA oleh SKPD belum dapat membantu mencapai tujuan organisasi pemerintah daerah secara maksimal. Penelitian yang dilakukan oleh Azzindani et al. (2019) menunjukkan hasil yang berbeda bahwa SIMDA berpengaruh terhadap laporan keuangan pemerintah daerah di Lombok Tengah. Penelitian Alfian (2015) juga menunjukkan adanya pengaruh SIMDA terhadap kualitas laporan keuangan daerah. Penelitian yang dilakukan oleh Alfiani (2017) pada pemerintah Kabupaten Tegal dan Ryanlie (2014) di daerah Minahasa Tenggara juga menemukan adanya pengaruh antara SIMDA dengan kualitas laporan keuangan daerah. Namun hasil yang berbeda ditemukan kembali pada penelitian (Mohune, 2013) menyatakan bahwa SIMDA memiliki pengaruh negatif terhadap kualitas laporan keuangan daerah.

Faktor lain yang sangat penting dan mempengaruhi kualitas laporan keuangan daerah adalah good governance. Pengelolaan keuangan daerah pada organisasi sektor publik dituntut agar memiliki tata kelola yang baik (good governance) untuk kepentingan masyarakat dan tanggap akan tuntutan lingkungannya. Prinsip good governance merupakan prinsip pokok yang harus diberlakukan di seluruh negara di dunia termasuk Indonesia Nugraheni \& Subaweh (2008) . Spathis (2002) menyatakan bahwa adanya tuntutan masyarakat 
terhadap peningkatan transparansi dan konsistensi informasi yang dilihat dalam laporan keuangan, oleh karena itu penerapan good governance dalam organisasi sektor publik diharapkan dapat menghasilkan laporan keuangan yang berkualitas terbebas dari penyajian data yang belum sesuai dengan peraturan dan terbebas dari penyimpangan-penyimpangan. Berdasarkan penelitian yang dilakukan oleh Manuppan (2015), menyimpulkan bahwa good governance berpengaruh positif terhadap kualitas laporan keuangan. Sejalan dengan penelitian diatas Herawati (2014) menyatakan good governace berpengaruh positif terhadap kualitas laporan keuangan daerah. Penelitian yang dilakukan Kesuma, Anwar, \& Darmansyah (2017) juga menyatakan good governace memiliki pengaruh yang signifikan terhadap kualitas laporan keuangan daerah. Sedangkan penelitian yang dilakukan Novatiani dan Jeanny (2012) menemukan hasil yang berbeda yaitu good governace memiliki pengaruh negatif terhadap kualitas laporan keuangan daerah.

Badan Pemeriksa Keuangan (BPK) Perwakilan Provinsi Bali menilai sejumlah pemerintah daerah sudah serius dalam mengelola aset jika dilihat dari Laporan Hasil Pemeriksaan tahun 2018 di Provinsi Bali. Kemudian, Laporan Hasil Pemeriksaan (LHP) tersebut mengungkapkan bahwa Pemerintah Daerah Kabupaten Jembrana sudah mendapatkan opini Wajar Tanpa Pengecualian (WTP). Ikhtisar Hasil Pemeriksaan Semester (IHPS) BPK Provinsi Bali (2019) memberikan opini Wajar Tanpa Pengecualian kepada pemerintah Kabupaten Jembrana, tetapi masih memiliki kelemahan pada sistem pengendaliaan intern pemerintah, hal ini membuktikan bahwa kurangnya pemahaman tentang sistem pengendaliaan intern pemerintah dan pemanfaatan teknologi informasi. BPK menemukan beberapa kelemahan pada sistem pengendalian akuntansi dan pelaporan yaitu pencatatan belum/tidak dilakukan secara akurat, proses penyusunan laporan tidak sesuai dengan ketentuan, sistem informasi akuntansi dan pelaporan belum didukung sumber daya manusia yang memadai.

Agency teori menyatakan bahwa SPIP harus diterapkan dalam penyusunan laporan keuangan daerah karena pemerintah daerah bertanggung jawab atas kualitas laporan keuangan daerah terhadap masyarakat daerah. SPIP yang baik akan menjamin dihasilkan laporan keuangan yang berkualitas. Dalam rangka meningkatkan kualitas laporan keuangan, pemerintah daerah harus senantiasa meningkatkan kegiatan pengendalian dengan mempertimbangkan pelimpahan tugas secara sistematik ke sejumlah orang untuk memberikan keyakinan check dan balances. Sistem Pengendalian Intern Pemerintah (SPIP) di lingkungan instansi pemerintah dikenal sebagai suatu sistem yang diciptakan untuk mendukung upaya agar penyelenggaraan kegiatan pada instansi pemerintahan dapat mencapai tujuannya secara efisien dan efektif, dimana pengelolaan keuangan negara dapat dilaporkan secara andal, aset negara dapat dikelola dengan aman, dan tentunya mendorong ketaatan terhadap peraturan perundang-undangan Mulyani \& Suryawati (2013).

Laporan keuangan yang berkualitas merupakan kebutuhan dari masyarakat selaku prinsipal. Dalam memenuhi kebutuhan tersebut, sistem pengendalian intern pemerintah harus memadai. Adanya sistem pengendalian intern yang baik, maka segala kegiatan terutama dibidang keuangan akan berjalan sesuai dengan prosedur, sehingga mampu menghasilkan laporan 
keuangan yang berkualitas. Hal tersebut didukung dengan penelitian yang dilakukan sebelumnya oleh Dewi (2014) yang menyatakan bahwa sistem pengendalian intern berpengaruh positif terhadap kualitas laporan keuangan. Penelitan Sudiarianti (2015), Agustiawan (2016) serta Elvin dan Diana (2018) menyatakan bahwa SPIP berpengaruh positif terhadap kualitas laporan keuangan. Berdasarkan uraian dan hasil penelitian sebelumnya maka hipotesis yang dapat dikemukan adalah:

$\mathrm{H}_{1}$ : Sistem pengendalian intern pemerintah berpengaruh positif pada kualitas laporan keuangan daerah.

Teori kepatuhan menyatakan penyusunan laporan keuangan daerah yang berkualitas dilakukan dengan profesionalisme dengan mematuhi standar akuntansi yang sudah ditetapkan guna mewujudkan praktik pengelolaan keuangan daerah yang cepat, tepat, dan akurat. Sistem Informasi Manajemen Daerah (SIMDA) sebuah sistem berbasis aplikasi teknologi yang dikembangkan Badan Pengawas Keuangan dan Pembangunan (BPKP) untuk mendukung tercapainya akuntabilitas bagi pemerintah daerah baik ditingkat pelaporan (SKPKD) ataupun ditingkat akuntansi (SKPD). Aplikasi ini diharapkan dapat membantu pemerintah daerah dalam penyusunan perencanaan dan penganggaran, serta pelaksanaan dan penatausahaan APBD dan pertanggungjawaban APBD.

Hal tersebut didukung oleh beberapa penelitian terdahulu seperti penelitian yang dilakukan oleh Mohune (2013) yang menyatakan adanya pengaruh signifikan dari penerapan SIMDA terhadap kualitas laporan keuangan di Pemda Gorontalo. Demikian juga dengan penelitian Salehi dan Rostami (2010), Kamal dan Noermansyah (2015) yang menemukan adanya pengaruh positif dari penerapan SIMDA terhadap kualitas laporan keuangan. Dari penjelasan sebelumnya maka dapat dirumuskan hipotesis sebagai berikut:

$\mathrm{H}_{2}$ : Sistem informasi manajemen keuangan daerah berpengaruh positif pada kualitas laporan keuangan daerah.

Teori agen merupakan dasar yang di gunakan dalam pelaksanaan good governance pada penyusunan laporan keuangan daerah, karena pengelolaan keuangan yang baik akan membantu pemerintah daerah dalam menyusun laporan keuangan yang akan dipertanggung jawabkan ke pemerintah pusat dan masyarakat. Konsep good governance mempunyai arti yang luas, dipahami secara berbeda tergantung pada konteksnya Batubara (2006). Pengelolaan keuangan secara efektif setiap OPD di pemerintah daerah merupakan salah satu pelayanan publik yang dapat dilakukan untuk pembiayaan operasional kepada masyarakat, hal tersebut dapat didukung dengan menerapkan 9 karakteristik good governance yaitu: partisipasi, taat hukum, transparansi, daya tanggap, kesetaraan, efektifitas dan efesiensi, akuntabilitas, visi strategis, orientasi konseus.

Pengelolaan keuangan OPD yang menerapkan good governance secara efektif sangat potensial dalam menentukan kualitas pelaporan keuangan pemerintah daerah yang diberi kewenangan untuk megatur daerahnya sendiri dan kemudian akan dipertanggung jawabkan kepada pemerintah pusat dan masyarakat. Hal ini sejalan dengan penelitian penelitian Darwanis (2012)yang membuktikan bahwa penerapan good governance berpengaruh pada kualitas informasi keuangan SKPD di Kota Banda Aceh. Boekorsjom (2013) juga 
menunjukkan hasil bahwa penerapan good governance berpengaruh positif terhadap kualitas informasi keuangan. Demikian juga dengan Handayani (2012) menyatakan bahwa good governance memiliki pengaruh yang positif terhadap laporan keuangan pemerintah daerah.

$\mathrm{H}_{3}$ : Good governance berpengaruh positif pada kualitas laporan keuangan daerah.

\section{METODE PENELITIAN}

Penelitian ini dilakukan di seluruh OPD Kabupaten Jembrana Bali. Daftar Nama OPD di Kabupaten Jembrana. Obyek penelitian adalah ketepatan pemberian opini yang dipengaruhi oleh Sistem Pengendalian Intern Pemerintah (SPIP), Pengaruh Penerapan Sistem Informasi Manajemen Keuangan Daerah (SIMDA) dan, Good Governance, Terhadap Kualitas Laporan Keuangan Pemerintah Daerah Kabupaten Jembrana.

Variabel dependen yang digunakan dalam penelitian ini adalah kualitas laporan keuangan pemerintah daerah. Istilah Laporan Keuangan Pemerintah Daerah meliputi semua laporan dan berbagai penjelasannya yang mengakui laporannya tersebut akan diakui sebagai bagian dari laporan keuangan. Penelitian ini mengukur kualitas Laporan Keuangan Daerah dengan mengadopsi indikator yang digunakan oleh penelitian yaitu, relevan, handal, informasi dalam laporan keuangan dapat dibandingkan, informasi dalam laporan keuangan dapat dipahami, dan sesuai standar akuntansi. Variabel independen dalam penelitian ini adalah pengaruh sistem pengendalian intern pemerintah, sistem informasi manajemen keuangan daerah, dan good governance. Sistem Pengendalian Intern Pemerintah adalah Sistem Pengendalian Intern (SPI), yang diselenggarakan secara menyeluruh di lingkungan pemerintah pusat dan lingkungan pemerintah daerah. Penelitian ini mengukur Sistem Pengendalian Intern Pemerintah dengan mengadopsi indikator, yaitu lingkungan pengendalian, penilaian risiko, dokumen dan catatan yang memadai, aktivitas pengendalian, informasi dan komunikasi, dan pemantaauan. Sistem Informasi Manajemen Keuangan Daerah merupakan sebuah sistem pengelolaan keuangan daerah berbasis teknologi informasi yang dapat membantu pemerintah daerah dalam menghasilkan informasi keuangan yang relevan, cepat, akurat, lengkap dan dapat diuji kebenerannya. Penelitian ini mengukur SIMDA dengan mengadopsi indikator, yaitu ketersediaan komputer, tersedianya software, tersedianya jaringan internet, dan sistem akuntansi SKPD. Variabel penerapan good governance adalah konsep tata kelola pemerintahan yang solid dan bertanggung jawab yang sejalan dengan prinsip demokrasi dan pasar yang efisien. Penelitian ini mengukur good governance dengan mengadopsi indikator, yaitu participation, rule of law, transparency, responsiveness, consensus orientation, equity, efficiency and effectiveness, accountanbility, dan strategic vision.

Populasi pada penelitian ini adalah seluruh pegawai dibidang akuntansi/kebendaharaan pada setiap OPD di Pemerintahan Kabupaten Jembrana yang memahami dan mengetahui tentang Laporan Keuangan Daerah, SPIP, SIMDA, dan good governance. Jumlah pegawai pada bidang akuntansi/kebendaharaan pada OPD di Pemerintahan Kabupaten Jembrana yang menjadi populasi penelitian sebanyak 90 orang. 
Metode penentuan sampel yang digunakan pada penelitian ini adalah purposive sampling method, yaitu teknik pengambilan sampel berdasarkan kriteria atau pertimbangan tertentu. Kriteria pertimbangan yang digunakan dalam penentuan sampel adalah pegawai di bidang akuntansi/kebendaharaan yang membuat dan mengetahui SPIP, SIMDA, good governance serta laporan keuangan dan masa kerjanya lebih dari 3 tahun di seluruh OPD Pemerintah Daerah Kabupaten Jembrana. Jumlah responden penelitian adalah sebanyak 50 orang.

Metode pengumpulan data yang digunakan yaitu, teknik kuesioner merupakan teknik pengumpulan data yang dilakukan dengan cara memberikan seperangkat pertanyaan atau pernyataan tertulis kepada responden untuk dijawab. Kuesioner tersebut diberikan kepada responden dengan diantar langsung oleh peneliti. Kuisioner di bagikan kepada para pegawai yang bekerja pada bidang bendahara di setiap OPD Pemerintah Kabupaten Jembrana. Dokumentasi adalah teknik pengumpulan data dengan mencatat, mengutip serta mengumpulkan data dari dokumen-dokumen. Dalam penelitian ini, data yang diperoleh dari teknik dokumentasi seperti data mengenai jumlah Pegawai dibidang bendahara di setiap OPDPemerintah Daerah Kabupaten Jembrana dan namaBadan/Dinas di Pemerintah Kabupaten Jembrana yang digunakan sebagai sampel.

Analisis regresi berganda digunakan untuk mengetahui atau memperoleh gambaran mengenai pengaruh variabel Sistem Pengendalian Intern Pemerintah (SPIP) (X1), Sistem Informasi Manajemen Keuangan Daerah (SIMDA) (X2), Good Governance (X3) Kualitas Laporan Keuangan Daerah (Y) dengan bantuan program SPSS. Model regresi linier berganda yang digunakan adalah dengan menggunakan rumus:

$$
Y=\alpha+\beta_{1} X_{1}+\beta_{2} X_{2}+\beta_{3} X_{3}+\varepsilon
$$

Keterangan:

$\begin{array}{ll}Y & : \text { Kualitas Laporan Keuangan Daerah } \\ \mathrm{a} & : \text { Nilai Konstanta } \\ \beta_{1} & : \text { Koefisien regresi } \\ \mathrm{X}_{1} & : \text { Sistem Pengendalian Intern Pemerintah (SPIP) } \\ \mathrm{X}_{2} & : \text { Sistem Informasi Manajemen Keuangan Daerah (SIMDA) } \\ \mathrm{X}_{3} & : \text { Good Governance } \\ \varepsilon & : \text { error terms }\end{array}$

\section{HASIL DAN PEMBAHASAN}

Pengaruh variabel SPIP, SIMDA, dan good governance, pada kualitas laporan keuangan daerah diuji dengan menggunakan Uji t. Kriteria pengujian untuk menjelaskan interpretasi pengaruh antar masing-masing variabel yakni apabila nilai signifikansi $\leq$ 0,05 maka $\mathrm{H} 0$ ditolak dan $\mathrm{H} 1$ diterima. Sebaliknya, jika nilai signifikansi $>$ 0,05 maka H0 diterima dan H1 ditolak. Perhitungan koefisien regresi linier berganda dilakukan dengan analisis regresi melalui software SPSS 18.0 for Windows, diperoleh hasil yang ditunjukan pada Tabel 1.

Berdasarkan hasil analisis regresi linier berganda seperti yang disajikan pada Tabel 1, maka dapat dibuat persamaan regresi sebagai berikut.

$$
Y=-2,967+0,395 X_{1}+0,443 X_{2}+0,107 X_{3}
$$


Dari hasil perhitungan SPSS didapatkan perbandingan nilai sig.t SPIP sebesar 0,000 kurang dari nilai signifikan yang digunakan $(0,000<0,05)$, dan nilai beta pada Unstandardized Coefficients adalah 0,395 yang mengindikasikan ke arah positif. Hal tersebut menunjukkan bahwa SPIP berpengaruh positif dan signifikan terhadap kualitas laporan keuangan daerah yang berarti $\mathrm{H}_{0}$ ditolak dan $\mathrm{H}_{1}$ diterima.

Tabel 1. Hasil Analisis Regresi Linier Berganda

\begin{tabular}{|c|c|c|c|c|c|c|}
\hline \multicolumn{7}{|c|}{ Coefficients ${ }^{a}$} \\
\hline & & \multicolumn{2}{|c|}{$\begin{array}{l}\text { Unstandardized } \\
\text { Coefficients }\end{array}$} & $\begin{array}{l}\text { Standardized } \\
\text { Coefficients }\end{array}$ & \multirow[b]{2}{*}{$T$} & \multirow[b]{2}{*}{ Sig. } \\
\hline Model & & $B$ & $\begin{array}{l}\text { Std. } \\
\text { Error }\end{array}$ & Beta & & \\
\hline \multirow[t]{4}{*}{1} & (Constant) & $-2,967$ & 2,037 & & $-1,456$ & 0,152 \\
\hline & SPIP & 0,395 & 0,070 & 0,428 & 5,601 & 0,000 \\
\hline & SIMDA & 0,443 & 0,062 & 0,503 & 7,182 & 0,000 \\
\hline & GG & 0,107 & 0,042 & 0,149 & 2,539 & 0,015 \\
\hline
\end{tabular}

a. Dependent Variable: KLKD

Sumber: Data Penelitian, 2020

Nilai sig.t SIMDA sebesar 0,000 kurang dari nilai signifikan yang digunakan $(0,000<0,05)$, dan nilai beta pada Unstandardized Coefficientsadalah 0,443 yang mengindikasikan ke arah positif. Hal tersebut menunjukkan bahwa SIMDA berpengaruh positif dan signifikan terhadap kualitas laporan keuangan daerah yang berarti $\mathrm{H}_{0}$ ditolak dan $\mathrm{H}_{2}$ diterima.

Nilai sig.t good governancesebesar 0,015 kurang dari nilai signifikan yang digunakan $(0,015<0,05)$, dan nilai beta pada Unstandardized Coefficients adalah 0,107 yang mengindikasikan ke arah positif. Hal tersebut menunjukkan bahwa Good Governanceberpengaruh positif dan signifikan terhadap kualitas laporan keuangan daerah yang berarti $\mathrm{H}_{0}$ ditolak dan $\mathrm{H}_{3}$ diterima.

Uji statistik F pada dasarnya menunjukkan apakah semua variabel bebas yang dimasukkan dalam model mempunyai pengaruh pada variabel dependen atau terikat. Uji statistik $\mathrm{F}$ dilakukan dengan melihat nilai signifikansi pada tabel ANOVA. Apabila nilai signifikansi ANOVA $\leq a$ dengan $a=5 \%$ maka model dikatakan layak. Hasil uji F dapat dilihat pada Tabel 2.

Tabel 2. Hasil Uji Kelayakan Model (Uji F)

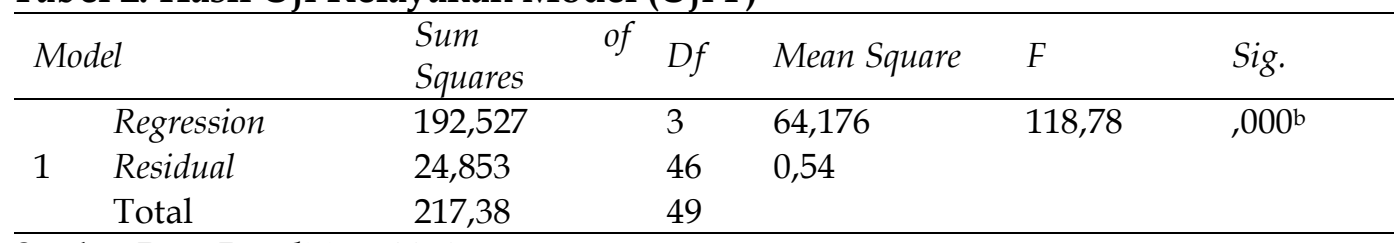

Sumber: Data Penelitian, 2019

Sesuai pengamatan diatas nilai signifikasi tabel ANOVA bernilai 0,000, berarti nilai tabel ANOVA lebih kecil dari 5\%. Disimpulkan bahwa model dalam penelitian adalah layak.

Ghozali (2016) menyatakan koefisien determinasi pada intinya digunakan untuk mengukur seberapa jauh kemampuan model dalam menerangkan kemampuan variabel terikat, sedangkan sisanya dijelaskan oleh sebab-sebab lain diluar model. Adapun hasil uji koefisien determinasi dalam penelitian ini dapat dilihat pada Tabel 3. 
Tabel 3. Hasil Uji Determinasi $\left(\mathbf{R}^{2}\right)$

\begin{tabular}{llllll}
\hline Model & $R$ & $R$ Square & $\begin{array}{l}\text { Mdjusted } \\
\text { Square }\end{array}$ & $R$ & $\begin{array}{l}\text { Std. Error of the } \\
\text { Estimate }\end{array}$ \\
\hline 1 &, $941^{\mathrm{a}}$ & 0,886 & 0,878 & 0,73504 \\
\hline
\end{tabular}

Sumber: Data Penelitian, 2020

Sesuai tabel model summary nilai $\mathrm{R}^{2}$ 0,886 atau $88,6 \%$, artinya variabel kualitas laporan keuangan dapat dijelaskan oleh variabel SPIP, SIMDA, dan Corporate Governance sebesar $88,6 \%$ sedangkan $11,4 \%$ atau sisanya dipengaruhi oleh variabel lain.

Pengaruh variabel SPIP, SIMDA, dan good governance, pada kualitas laporan keuangan daerah diuji dengan menggunakan Uji t. Kriteria pengujian untuk menjelaskan interpretasi pengaruh antar masing-masing variabel yakni apabila nilai signifikansi $\leq 0,05$ maka H0 ditolak dan H1 diterima. Sebaliknya, jika nilai signifikansi > 0,05 maka $\mathrm{H} 0$ diterima dan $\mathrm{H} 1$ ditolak. Adapun hasil uji t dalam penelitian ini dapat dilihat pada Tabel 4 .

Dari hasil perhitungan SPSS didapatkan perbandingan nilai sig.t SPIP sebesar 0,000 kurang dari nilai signifikan yang digunakan $(0,000<0,05)$, dan nilai beta pada standardized coefficients adalah 0,428 yang mengindikasikan ke arah positif. Hal tersebut menunjukkan bahwa SPIP berpengaruh positif dan signifikan terhadap kualitas laporan keuangan daerah yang berarti $\mathrm{H}_{0}$ ditolak dan $\mathrm{H}_{1}$ diterima.

Tabel 4. Hasil Hipotesis t

\begin{tabular}{|c|c|c|c|c|c|c|}
\hline \multirow{2}{*}{\multicolumn{2}{|c|}{ Model }} & \multicolumn{2}{|c|}{$\begin{array}{l}\text { Unstandardized } \\
\text { Coefficients }\end{array}$} & \multirow{2}{*}{$\begin{array}{l}\text { Standardized } \\
\text { Coefficients } \\
\text { Beta } \\
\end{array}$} & \multirow[t]{2}{*}{$T$} & \multirow[t]{2}{*}{ Sig. } \\
\hline & & $B$ & Std. Error & & & \\
\hline \multirow{4}{*}{1} & (Constant) & $-2,967$ & 2,037 & & $-1,456$ & 0,152 \\
\hline & SPIP & 0,395 & 0,07 & 0,428 & 5,601 & 0,000 \\
\hline & SIMDA & 0,443 & 0,062 & 0,503 & 7,182 & 0,000 \\
\hline & CG & 0,107 & 0,042 & 0,149 & 2,539 & 0,015 \\
\hline
\end{tabular}

Sumber: Data Penelitian, 2020

Nilai sig.t SIMDA sebesar 0,000 kurang dari nilai signifikan yang digunakan $(0,000<0,05)$, dan nilai beta pada standardized coefficients adalah 0,503 yang mengindikasikan ke arah positif. Hal tersebut menunjukkan bahwa SIMDA berpengaruh positif dan signifikan terhadap kualitas laporan keuangan daerah yang berarti $\mathrm{H}_{0}$ ditolak dan $\mathrm{H}_{2}$ diterima.

Nilai sig.t good governance sebesar 0,015 kurang dari nilai signifikan yang digunakan $(0,015<0,05)$, dan nilai beta pada standardized coefficients adalah 0,149 yang mengindikasikan ke arah positif. Hal tersebut menunjukkan bahwa Good Governance berpengaruh positif dan signifikan terhadap kualitas laporan keuangan daerah yang berarti $\mathrm{H}_{0}$ ditolak dan $\mathrm{H}_{3}$ diterima.

Hipotesis pertama menyatakan bahwa Sistem Pengendalian Intern Pemerintah (SPIP) berpengaruh positif pada keterikatan kualitas laporan keuangan daerah. Artinya sistem pengendalian intern pemerintah yang diterapkan dapat mempengaruhi tingkat kualitas laporan kuangan daerah, sehingga semakin tinggi sistem pengendalian intern pemerintah yang diterapkan kepada pegawai maka semakin tinggi pula tingkat tingkat kualitas laporan keuangan yang dihasilkan. 
Hasil ini mendukung penelitian sebelumnya yang dilakukan oleh Sudiarianti (2015), Agustiawan (2016), dan Elvin \& Diana (2018)yang menunjukkan bahwa variabel sistem pengendalian intern pemerintah secara positif mempengaruhi kualitas laporan keuangan daerah. Hal ini senada dengan penelitian yang dilakukan oleh penelitian Desianawati (2014) yang menemukan bahwa terdapat pengaruh antara sistem pengendalian intern pemerintah dengan kualitas laporan keuangan daerah. Berdasarkan agency teori dan teori kepatuhan yang digunakan sebagai dasar, pemerintah membuat laporan keuanganya dengan mematuhi standar dari sistem pengendalian intern pemerintah yang sudah ditetapkan dan mempertanggungjawabkan laporan keuangannya kepada masyarakat.

Berdasarkan pengujian hipotesis kedua yaitu Sistem Informasi Manajemen Keuangan Daerah (SIMDA) berpengaruh positif pada kualitas laporan keuangan daerah. Artinya sistem informasi manajemen keuangan daerah yang diterapkan dapat mempengaruhi tingkat kualitas laporan kuangan daerah, sehingga semakin tinggi sistem informasi manajemen keuangan daerah yang diterapkan kepada pegawai maka semakin tinggi pula tingkat tingkat kualitas laporan keuangan yang dihasilkan.

Hasil ini mendukung penelitian sebelumnya yang dilakukan oleh Alfian (2015) dan Alfiani (2017) yang menunjukkan bahwa variabel sistem informasi manajemen keuangan daerah secara positif mempengaruhi kualitas laporan keuangan daerah. Penelitian ini juga mendukung penelitian Ryanlie (2014) yang menyatakan tingkat sistem informasi manajemen keuangan daerah yang diterapkan pada pemerintahan di daerah Minahasa Tenggara mempunyai dampak yang signifikan pada keterikatan kualitas laporan keuangan daerah tersebut tersebut. Hasil penelitian hipotesis ketiga menunjukkan good governance berpengaruh positif pada kualitas laporan keuangan daerah. Artinya semakin tinggi penerapan good governance maka kualitas laporan keuangan daerah akan semakin tinggi yang akan berdampak pada opini yang diberikan oleh BPK, dimana semakin baik dan berkualitasnya laporan keuangan akan menghasilkan opini WTP.

Hasil ini mendukung penelitian sebelumnya yang dilakukan oleh Kesuma \& Darmansyah (2017) dan Herawati (2014) yang menunjukkan bahwa good governance berpengaruh positif signifikan terhadap kualitas laporan keuangan daerah. Hal ini sejalan dengan penelitian yang dilakukan oleh Darwanis (2012) yang menunjukankan bahwa good governance berpengaruh positif dan signifikan terhadap kualitas laporan keuangan daerah. Berdasarkan agency teori dan teori kepatuhan yang digunakan sebagai dasar, pemerintah daerah mengelola pemerintahan dengan baik, dengan membuat laporan keuanganya dengan mematuhi standar-standar yang sudah ditetapkan dengan tata kelola yang baik dan mempertanggungjawabkan laporan keuangannya pada masyarakat.

\section{SIMPULAN}

Hasil yang ditunjukkan dari penelitian ini yang dinyatakan oleh teori-teori yang digunakan memberikan pemahaman mengenai pengaruh SPIP, SIMDA dan good governance di pemerintahan Kabupaten Jembrana berpengaruh positif terhadap kualitas laporan keuangan. Penelitian ini menambah wawasan tentang faktor- 
faktor yang mempengaruhi laporan keuangan daerah dan hendaknya menjadi bahan evaluasi untuk pemerintah daerah agar lebih meningkatkan kualiatas laporan keuangan daerah. Bagi pemerintah Kabupaten Jembrana penelitian ini diharapkan menjadi bahan evaluasi yang mampu meningkatkan penggunaan sistem keuangan daerah agar menghasilkan kualitas laporan keuangan yang baik.

\section{REFERENSI}

Agustiawan, N. T., \& Rasmini, N. K. (2016). Pengaruh Sistem Berbasis Akrual, TI, dan SPIP Pada Kualitas Laporan Keuangan kompetensi Kompetensi SDM Sebagai Moderasi. E-Jurnal Ekonomi Dan Bisnis Universitas Udayana, 5.10(3475-3500).

Alfian, M. (2015). Faktor-faktor yang mempengaruhi implementasi SIMDA dan kualitas laporan keuangan SKPD. Jurnal Akuntansi Dan Investasi,.

Alfiani. (2017). Jumlah Temuan Audit Atas Sistem Pengendalian Intern Dan Jumlah Temuan Audit Atas Kepatuhan Terhadap Opini Laporan Keuangan Pemerintah Daerah. Jurnal Riset Akuntansi Kontemporer (JRAK), 9(1). http://dx.doi.org/10.23969/jrak.v9i1.362

Azzindani, R., Pituringsih, E., \& dan M. Irwan. (2019). Pengaruh Implementasi SIMDA, KinerjaAparatur Pemerintah Daerah dan Penerapan SAP TerhadapKualitasLKPD Lombok Tengah. E-Jurnal Akuntansi Universitas Udayana, 27 (ISSN: 2302-8556). https:// doi.org/10.24843/EJA.2019.v27.i01.p16

Batubara, A. H. (2006). Konsep Good Governance dalam Konsep Otonomi Daerah. Jurnal Analisis Administrasi Dan Kebijakan.

Boekorsjom, F. J. (2013). Pengaruh Penatausahaan Keuangan Daerah Terhadap Penerapan Good Governance Dan Implikasinya Terhadap Kualitas Informasi Keuangan Pada Bpkad Provinsi Papua. Universitas Komputer Indonesia Papua.

Desianawati. (2014). Pengaruh Kualitas SDM, Penerapan SAP, dan Sistem Akuntansi Keuangan Daerah Terhadap Kualitas Laporan Keuangan Daerah. E-Journal S1 Ak, Universitas Pendidikan Ganesha, 2(1). http://dx.doi.org/10.23887/jimat.v2i1.2972

Devi. (2013). Pengaruh Implementasi Sistem Informasi Akuntansi Terhadap Kinerja Organisasi Pemerintah Daerah (Penelitian pada SKPD di Lingkungan Pemerintah Daerah Kabupaten Kulon Progo). Yogyakarta: Universitas Muhammadiyah Yogyakarta.

Dewi, A. F. (2014). Analisis Kualitas Laporan Keuangan Pemerintah Daerah (Studi Kasus Pada Satuan Kerja Perangkat Daerah Kabupaten Serdang Bedagai). E-Journal S1 Ak, Uuniversitas Islam Negeri Sumatera Utara Medan.

Ghozali, H. I. (2016). Aplikasi Analisis Multivariate dengan Program IBM SPSS 21 (P. P. Harto (ed.); Edisi 8). Badan Penerbit Universitas Diponegoro.

Handayani, D. (2012). Good Government Governance dan Kualitas Laporan Keuangan Pemerintah. Jurnal Akuntansi Keuangan Dan Bisnis, 5.

Herawati, T. (2014). Pengaruh Sistem Pengendalian Intern Terhadap Kualitas Laporan Keuangan (Survei Pada Organisasi Perangkat Daerah PemdaCianjur). IHPS BPK, tahun 2011-2019

Indriya. (2013). Pengaruh Sistem Pengendalian Intern Pemerintah (Spip) Terhadap 
Kualitas Laporan Keuangan Dan Implikasinya Terhadap Akuntabilitas Keuangan: Penelitian Pada Laporan Realisasi Anggaran di Pemerintah Daerah Kabupaten Wilayah Provinsi Jawa Barat. Pendidikan Indonesia.

Insani, I. (2010). Pengembangan Kapasitas Sumber Daya Manusia Pemerintah Daerah dalam Rangka Peningkatan Transparansi dan Akuntabilitas Pengelolaan Keuangan Daerah. Penyempurnaan Makalah pada Workshop Manajemen Perkantoran di Lingkungan Kementerian Komunikasi dan Informatika. Bandung.

Kamal, B., \& Noermansyah, A. L. (2015). Analisis Faktor Yang Mempengaruhi Implemetasi SIMDA dan Kualitas Laporan Keuangan Pada SKPD. Jurnal of Politeknik Harapan Bersama Tegal.

Kesuma, D. P., Anwar, C., dan Darmansyah, D. (2017). Pengaruh Good Governance, Penerapan Standar Akuntansi Pemerintah, Sistem Pengendalian Internal Pemerintah Dan Kompetensi Aparatur Pemerintah Terhadap Kualitas Laporan Keuangan Pemerintah Pada Satuan Kerja Kementerian Pariwisata. E-Journal Widya Ekonomika, 1(1).

Manuppan, B. T. (2015). Pengaruh Good Governance, Kompetensi Sumber Daya Manusia, dan Sistem Pengendalian Intern Terhadap Kualitas Informasi Laporan Keuangan. Jom Fekon, 2(No.2 ISSN 2355-6854).

Mohune, C. (2013). Pengaruh Penerapan Sistem Informasi Manajemen Daerah (SIMDA) terhadap Kualitas Laporan Keuangan. Gorontalo.

Mulyani, P., \& Suryawati, R. F. (2013). Analisis Peran dan Fungsi Sistem Pengendalian Intern Pemerintah (X3.P/PP No. 60 Tahun 2008) dalam Meminimalisasi Tingkat Salah Saji Pencatatan Akuntansi Keuangan Pemerintah Daerah. Jurnal Organisasi Dan Manajemen, 13(5)(pp: 102-116).

Novatiani, R. A., \& dan Jeanny, F. (2012). Pengaruh Penerapan Good Corporate Governance Terhadap Kualitas Laporan Keuangan. Jurnal Akuntans. https:// doi.org/10.29103/jak.v6i1.1823

Nugraheni, P., \& dan Subaweh, I. (2008). Pengaruh Penerapan Standar Akuntansi Pemerintahan Terhadap Kualitas Laporan Keuangan. Jurnal Ekonomi Bisnis, 13(1). http:// dx.doi.org/10.35760/eb.2008.v13i1.321

Ryanlie. (2014). Analisis Implementasi Sistem Informasi Manajemen Daerah (Simda) Terhadap Kualitas Laporan Keuangan Skpd (Studi Kasus Pada Dinas Ppkad Kabupaten Minahasa Tenggara). Accountability, 3(2). https:// doi.org/10.32400/ja.6419.3.2.2014.1-15

Salehi, M., V. Rostami, dan A. M. (2010). Usefulness of accountinginformation system in emerging economy: empirical evidence of Iran. International Journal of Economics and Finance, 2(2). 10.5539/ijef.v2n2p186

Spathis, C. T. (2002). Detecting False Financial Statements Using Published Data: Some Evidence from Greece. Managerial Auditing Journal, 17(4)(179-191).

Sudiarianti, N. . (2015a). Pengaruh Kompetensi Sumber Datya Manusia Pada Penerapan Sistem Pengendalian Intern Pmerintah dan Satndar Akuntansi Pemerintah Serta Implikasinya Pada Kualitas Laporan Keuangan Pemerintah Daerah. Universitas Udayana.

Sudiarianti, N. . (2015b). Pengaruh Kompetensi Sumber Datya Manusia Pada Penerapan Sistem Pengendalian Intern Pmerintah dan Satndar Akuntansi Pmerintah Serta Implikasinya Pada Kualitas Laporan Keuangan Pemerintah Daerah. Udayana. 
Susilawati \& Dwi Seftihani Riana. (2014). Standar Akuntansi Pemerintahan dan Sistem Pengendalian Intern Sebagai Anteseden Kualitas Laporan Keuangan Pemerintah Daerah. STAR-Study \& Accounting Rese, XI(1).

Widyaningsih, A. (2009). Hubungan Efektivitas Sistem Akuntansi Keuangan Daerah dan Pengendalian Intern dengan Kualitas Akuntabilitas Keuangan: Kualitas Informasi Laporan Keuangan sebagai Variabel Intervening (Penelitian pada Laporan Realisasi Anggaran di Pemda Kabupaten/Kota Wila. Program Pascasarjana Universitas Padjadjaran. Bandung. 